\title{
The Creation of Teaching Aids for Disabled Students as Mathematical- Thinking-Imaginative Product
}

\section{Sugiman}

Lecturer of Mathematics Department of Universitas Negeri Semarang, Indonesia, sugimanwp@mail.unnes.ac.id

\section{Hardi Suyitno}

Prof., Mathematics Department of Universitas Negeri Semarang, Indonesia, hhardisunnes@yahoo.com

\section{Iwan Junaedi}

Lecturer of Mathematics Department of Universitas Negeri Semarang, Indonesia, iwanjunmat@gmail.com

\section{Dwijanto}

Lecturer of Mathematics Department of Universitas Negeri Semarang, Indonesia, dwijanto5@gmail.com

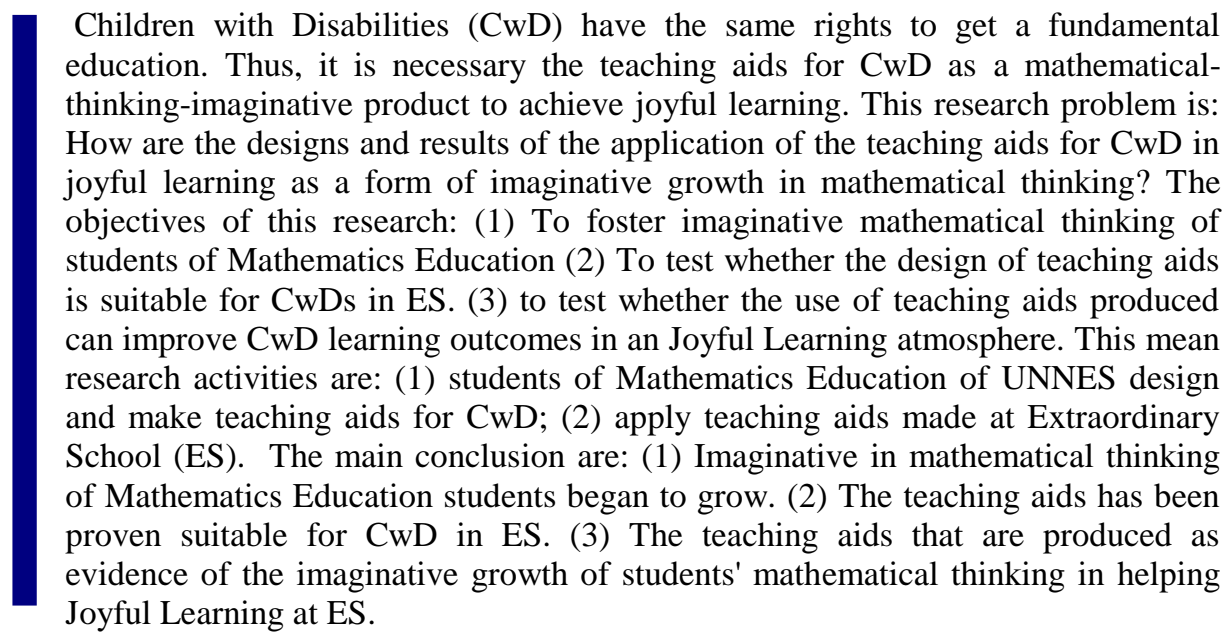

Keywords: mathematical thinking imaginative, ES, joyful learning, teaching aids, learning

Citation: Sugiman, Suyitno, H., Junaedi, I., \& Dwijanto. (2020). The Creation of Teaching Aids for Disabled Students as Mathematical-Thinking-Imaginative Product. International Journal of Instruction, 13(3), 777-788. https://doi.org/10.29333/iji.2020.13352a 


\section{INTRODUCTION}

Children with Special Needs are known as Children with Disabilities (CwD). CwD has the same rights to get a standard, effective, and sustainable education. Government and private parties have also organized Extraordinary School (ES) and Inclusive School.

Ideally, the $\mathrm{CwD}$ should be able to continue their education at Senior High School, even to College. In fact, almost all of ES are not ready with the procurement of teachers based on ES, especially at Secondary School level. Students of Mathematics Education of Universitas Negeri Semarang are quite interested in being a math teacher in ES at Junior High or Senior High School level. However, facilities, infrastructure, and regulations have not been possible to produce mathematics teachers for $\mathrm{CwD}$.

Thus, there is a gap between the real needs in the field and the facts that exist in the college. ES requires math teachers who are professional in the material field, but also master the needs of $\mathrm{CwD}$ in learning. On the other hand, universities, especially Mathematics Education, FMIPA UNNES, do not have regulation to produce the math teachers who are ready to teach in ES or inclusive school with all the consequences. Elements novelty that studied in this article is a form of design and application of teaching aids for $\mathrm{CwD}$ at $\mathrm{ES}$ based on the beginning of imaginative growth in mathematical thinking of Mathematics Education students in creating teaching aids for the $\mathrm{CwD}$ in the Joyful Learning.

Based on the background that has been described above, the research questions are: (1) How to design and manufacture teaching aids for $\mathrm{CwD}$ in Joyful Learning as the initial form of imaginative growth in mathematical thinking? (2) How is the result of the application of the teaching aids for CwD in ES to Joyful Learning as the initial form of imaginative growth in mathematical thinking? (3) How is the result of the test on the use of teaching aids produced in improving the learning outcomes of $\mathrm{CwD}$ in a Joyful Learning atmosphere?

\section{LITERATURE REVIEW}

\section{Extraordinary School for Children with Disabilities (CwD)}

Currently, the development of the education world has snowballed; this can be seen from the changing educational paradigm. Changes in the education curriculum mark this paradigm-changing. This change also affects education services $\mathrm{CwD}$. This is in line with the Law of the Republic of Indonesia Number 20 the Year 2003 about National Education System, Chapter IV Article 5 Paragraph (1) which reads:

Every citizen has the same right to obtain the quality education. Thus all citizens have the same rights, are not distinguished physically, ethnically, regarding religion, and others to obtain the high quality in education. Therefore, for children with physical, mental, emotional, and social disorders $(\mathrm{CwD})$, they have rights to a high quality in education. It is also mentioned in Article 32 Paragraph 1 of Law of Number 20 the Year 2003, which reads: special education is an education for students who have difficulty in following the learning process because of physical, emotional, mental, social, and have the potential of intelligence and talent special. 
Education service system for $\mathrm{CwD}$ can be done in segregation and integration. The segregation education system is an education system which is separated from the normal child education system. Education of CwD through segregation system means that the implementation of education is carried out specifically and separated from the provision of the formal education for normal children.

In other words, $\mathrm{CwD}$ is given educational services to special educational institutions for special of the needs children, such as Extraordinary School (ES) including Primary School of Extraordinary (PSE), Junior High School of Extraordinary (JHSE), and Senior High School of Extraordinary (SHSE).

The form of integrated education services is an education system that provides opportunities for $\mathrm{CwD}$ to learn together with the normal children for learning in one roof. It is known as Inclusive Education. Integration education system is also called an integrated education system that is an education system that brings CwD to the atmosphere of integration with the normal children.

Such integration can be comprehensive, in part, integrated into the framework of socialization. On a full and partial alignment system, the number of $\mathrm{CwD}$ in a class is up to $10 \%$ of the total the number of students. In one class, there is only one type of abnormality. The teacher's burden is easier than if the teacher has to handle for the several disabilities of students.

Math lessons are often called as difficult lessons, especially for CwD. Therefore, the researcher as the Head of Learning Study Center for CwD - FMIPA UNNES wanted to research how to grow imaginative in mathematical thinking for Mathematics Education students in creating Teaching Aids for CwD through Joyful Learning.

Thus, it is necessary to provide a forum for training and mentoring activities in creating teaching aids for CwD through Joyful Learning, to students of Mathematics Education of UNNES. Furthermore, the early growth of imaginative in mathematical thinking for the students of Mathematics Education in creating the teaching aids for $\mathrm{CwD}$ can be observed and followed up, so that the success of learning in ES with Joyful Learning nuances can be studied furthermore.

\section{Early Forum for Imaginative Growth in Mathematical Thinking}

Without imagination, it is difficult to conceptualize mathematics for $\mathrm{CwD}$, mathematics learning, or other science. Without imagination, the Egyptians would not be able to build pyramids, (Afiff, 2013). With the imagination of the likes of Bill Gates and Steve Jobs, who can imagine that someday there will be computers/laptops in every home, and has now manifested, who unimaginable by most people at that time. Naturally, imagination and knowledge cannot be separated.

Imagination is a cognitive process that is a complex mental activity in which elements in the mental activity are released from sensation senses, as stated by (Afiff, 2013). Imagination involves integrating aspects of memory, memories, or experiences into a mental construct that is different from the past and becomes a new reality in the present, or even the anticipation of reality in the future. Imagination is generally regarded as one 
of the "higher mental functions," and can also be associated with fantasies, dreams, or problem-solving forms that has algorithm different from the ordinary problem.

If this imagination is associated with mathematical thinking, then the nature of this imagination is called imaginative in mathematical thinking, (Liang et al, 2012). There are well-known words from Albert Einstein, an expert in Mathematics and Physics. According to Einstein, Imagination is more important than knowledge. For knowledge is limited to all we know and understand, while imagination embraces the entire world, and ever there will be to know and understand.

The emergence of imagination requires creativity, as wrote by (Cunningham, 2015). Imagination and creativity are needed in the future, including the demand for labor such as teachers. Raising the imaginative in this mathematical thinking, some expert opinions discuss it, which are as follows.

1) In order to elicit imaginative mathematical thinking, we need the indicator of: (1) fluency, which is the ability to generate many ideas; (2) flexibility, which is the ability to solve problems in various ways or approaches; (3) originality, which is the ability to express ideas of itself and in its own way; (4) elaboration (complete), which is the ability to explain something in detail; (5) redefinition, which is the ability to see a problem based on a different point of view from what others have found, Onal, et al (2017).

2) In order to elicit imaginative mathematical thinking, that needs the indicator of (1) flexibility, which is they have many different strategies to solve problem, (2) fluency, which is they able to produce different correct answers, (3) novelty, which has a new work, as wrote by (Suyitno, 2017).

Based on the description above, the combination of theories above can be modified by the research for this article. The indicators of the imaginative appearance in mathematical thinking to create teaching aids for $\mathrm{CwD}$ in the direction of learning Joyful Learning are as follows. (1) Emerging imagination or ideas that are marked with the production of teaching aids that are different from what has been found by others. (2) Fluency, which is the ability to produce teaching aid that can be utilized to describe several different materials. (3) Flexibility, which is the ability to produce some teaching aids that can be used to describe a material. (4) Originality, which is the ability to produce teaching aids as self-supporting works, (Onal, et al, 2017), (Suyitno, 2017), and (Zhu, et al, 2018).

\section{The design of Teaching Aids suitable for $\mathrm{CwD}$ and its activity container}

The following is the initial draft of manipulative teaching aids product for $\mathrm{CwD}$ which is expected to be the model for teaching aids created and made by students. This research activity will provide analysis results for the beginning of the growth of imagination that is innovative and creative in students Mathematics Education FMIPA UNNES to design and make Teaching Aids for $\mathrm{CwD}$ by the needs of children and friendly to the environment.

Example 1. In the book of ES students, there is Geometry material as shown in Figure 1. 


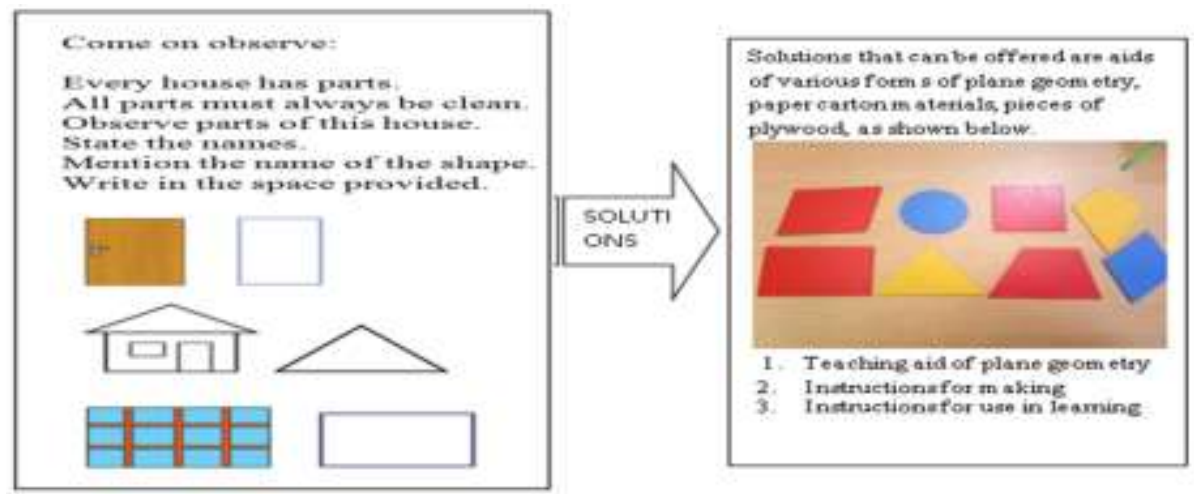

Figure 1

Models of Geometry Teaching Aids

In designing and making Teaching Aids, as a place of activity, students can do it outside the hours of the lecture or in a special meeting. Learning activities from informal sources occurring in extra-curricular training or out-of-study environments have proven to be effective and able to motivate participants, this is according to what was said by (Salmi \& Thuneberg, 2015).

Out door of learning makes learning environments especially useful for students, either because of the manipulation-oriented tool approach and contextualized reasoning which is not associated with a mere thought or mere symbols of manipulation. Training is necessary for teachers or teachers candidate to have the ability to develop professions and have high quality in the learning process which needed for students, as wrote by (Burns, 2011), (Harwell, 2003), and (Kramarz, 2008). The training materials should be very useful for teachers and students and must be suitable for current needs, (Doyran, 2012). If what is encountered is $\mathrm{CwD}$ then the material related to learning CwD is feasible to be studied and trained. With the existence of these teaching aids, it is expected mathematics subject matter to look easy and fun (Joyful Learning) for CwD.

About Joyful Learning, Joy according to the Oxford English Dictionary, is described as an emotion or a feeling of joy. This means that the mathematical learning process for CwD that utilizes teaching aids takes place "in a pleasant atmosphere and math becomes easy." Learning process or learning experience can make ES students or inclusion schools feel pleasant, as stated by (Wei, 2011). A pleasant learning perception has a positive effect on students' learning motivation, as said by (Wei, 2011) and (Conklin, 2014).

\section{METHOD}

\section{Research Approach}

This research used a qualitative approach. A qualitative approach has natural characteristics with data retrieval through direct data sources, descriptive, and processes are preferred to obtain accurate research results in line with the problems and objectives of the study. 


\section{Research focus}

Research Subject: The subject of this research is to take four students of Mathematics Education Study Program of FMIPA of UNNES who are interested in designing and making a teaching aids for $\mathrm{CwD}$ in ES. The focus of this research are as follows. To these students:

(1) given training with a pattern based on early observations of imaginative growth in students' Mathematical Thinking,

(2) given briefing and reading of letters and numbers of Braille, and its use in learning mathematics,

(3) researcher provided the example of model of mathematical teaching aids that suitable for CwD,

(4) given activities to create and make a mathematical teaching aids to learning of Joyful Learning, and

(5) researcher observed in depth the application of Teaching Aids for CwD in ES through Joyful Learning based on ECT, through: (a) The use of a mathematical teaching aids products by ES teachers. (b) Interview intensively on the subject of research. (c) Triangulation.

\section{Research Location}

This research was conducted at the Mathematics Department of Mathematics and Natural Sciences Faculty (FMIPA) of Universitas Negeri Semarang (UNNES) and ES of Salatiga.

\section{Research Data and Data Sources}

The research data source is the students of Mathematics Education Study Program of FMIPA of UNNES of Academic Year 2017/2018 who were interested in designing and making Teaching Aids that can be presented through learning by Joyful Learning and selected as the research subjects. The data is the result of CwD Teaching Aids created by students of Mathematics Education Study Program of FMIPA of UNNES to be analyzed/studied the beginning of their imaginative growth in mathematical thinking, creativity, behavior, activity, and the degree of Joyful Learning in the classroom.

\section{Data Collection Technique}

In this qualitative research, the data collection tool is the researcher himself. On the other hand, researchers have limitations in determining which data should be collected. Thus, researchers need tools to assess the learning process, guidelines for evaluating the use of teaching aids, interview guides, observation guides, diaries, and documentation studies to collect research data that is focused on problems that must be solved.

\section{Data Validity}

The collected data needs to be tested for validity to obtain objective data and by the purpose of this study. Some data validity testing techniques that can be used include an extension of time/research period, improved research persistence study, review of research subjects, additional interviews, and triangulation. The triangulation may consist of (1) triangulation of theories, (2) triangulation of sources, (3) triangulation of methods, or (4) triangulation of researchers. 


\section{Data Analysis and Interpretation}

The data analysis in this research includes data reduction, data presentation, data interpretation, conclusion and verification, (Tracy, 2013) and (Miles \& Huberman, 2014). Activities in the analysis of this qualitative data are carried out interactively and continue until the overall measure of the completeness of the required data has been fulfilled or new information is no longer needed, (Mayring, 2014).

(1) Data reduction is narrowly interpreted as a process of data reduction, but in a broader sense, is the process of improving the data, both the reduction of the data is less necessary or irrelevant, as well as the addition of data that is still lacking.

(2) Presentation of data is the process of gathering information organized by categories or groupings required.

(3) Interpretation of data is the process of understanding the meaning of a series of data that has been presented, in the form that not only sees what is written but more on understanding or interpreting about what is implied in the data that has been presented.

(4) The conclusion/verification is the process of formulating the meaning of the research results expressed in short, dense, and easily understood sentences, and done by repeatedly reviewing the truth of the inference, in particular about its relevance and consistency to the title, purpose, and formulation existing problems.

\section{The Initial Growth of Imaginative in Mathematical Thinking}

Disclosure of Imaginative in Mathematical Thinking, especially in creating teaching aids for $\mathrm{CwD}$, has never been done to students of Mathematics Education. Students only asked to make or create of teaching aids for the normal/regular students. Therefore, this research will reveal the initial growth of Imaginative in Mathematical Thinking, especially in creating of the teaching aids for $\mathrm{CwD}$. As described in the literature review above, then accordance with the purposes of this study, the early markers of imaginative growth in mathematical thinking in order to create teaching aids for CwD in the direction of Joyful Learning, then the indicators are as follows, (Suyitno, 2017), (Sriraman, 2017), and (Zhu, et al, 2018).

(1) The product of design marks growing imagination or ideas and making teaching aids that are different from those found by others.

(2) Fluency, that is, the ability to produce teaching aid that can be used to describe several different materials.

(3) Flexibility, which is the ability to produce some teaching aids that can be used to describe a material.

(4) Originality, the ability to produce teaching aids as self-supporting works.

After the product of the teaching aids is examined, a deep interview is conducted, then triangulation (comparing the findings at the time of judging and the interview) then the imaginative outcome in mathematical thinking to create teaching aids for CwD in Joyful Learning based on training recapitulated in 5 categories, that are: very good, good, medium, less, and very less. 
Table 1

Triangulation Result Data

\begin{tabular}{|c|c|c|c|}
\hline \multirow[t]{2}{*}{ No } & \multirow{2}{*}{$\begin{array}{l}\text { The beginning category of } \\
\text { imaginative growth in } \\
\text { mathematical thinking to create } \\
\text { props for CwD in the direction of } \\
\text { Joyful Learning. }\end{array}$} & \multicolumn{2}{|c|}{$\begin{array}{l}\text { Able to create props for CwD in the direction of Joyful Learning } \\
\text { after triangulation is implemented: }\end{array}$} \\
\hline & & Fluency fantasy imagination & Flexibility fantasy imagination \\
\hline 1. & Growing Very Good & There are 3 or more materials. & There are 3 or more teaching aids. \\
\hline 2. & Growing Good & There are two materials. & There are two teaching aids. \\
\hline 3. & Growing Medium & There is one material. & There are one teaching aids. \\
\hline 4. & Growing Less & $\begin{array}{l}\text { There is } 1 \text { material and it is } \\
\text { not appropriate to use. }\end{array}$ & $\begin{array}{l}\text { There is } 1 \text { material and it is not } \\
\text { appropriate to use. }\end{array}$ \\
\hline 5. & Growing Very Less & Failed. & Failed. \\
\hline
\end{tabular}

\section{FINDINGS}

\section{CwD Teaching Aids as a Beginning Form of Mathematical Imaginative Growth}

In the implementation of supporting research of this article, it has been conducted observation and selection of some students who have ideas and are interested to improve the quality of mathematics learning in ES. There are four students selected. Furthermore, the researcher conducted Focus Group Discussion (FGD), which was attended by a team of the researcher, lecturers of Mathematics Education who are interested, and selected students as mentioned above.

Based on FGD results, it has been agreed that the beginning of imaginative growth in students' mathematical thinking in creating Teaching Aids for $\mathrm{CwD}$, if a student can possess some abilities, as an early marker of mathematical imaginative growth. This marker is preceded by a series of activities as follows, namely to ask students to design, create, and simulate the use of props work of students concerned. The beginning markers of imagination in mathematical thinking are characterized by one of the following indicators:

(1) Students have an idea of imagination related to the design of Teaching Aids for CwD which is different from that already found by others.

(2) Students can realize the design of their imagination/ideas characterized by the production of visual aids that are fluency, which is the ability to produce teaching aids that can be utilized to explain some different materials through joyful learning.

(3) Students can realize the design of their imagination/ideas characterized by the resulting teaching aids that are flexible, which is the ability to produce some props that can be utilized to explain a material through joyful learning.

(4) Students can realize the design of their imagination/ideas characterized by the proliferation of props that are originality, which is the ability to produce props as competent work independently.

In this research had also found some models of mathematical teaching aids that are fluency, suitable for CwD studying in ES. One of them, shown in Figure 2 below.

Example 2. In the Mentally disabled class book, page 91, there was the following problem. 


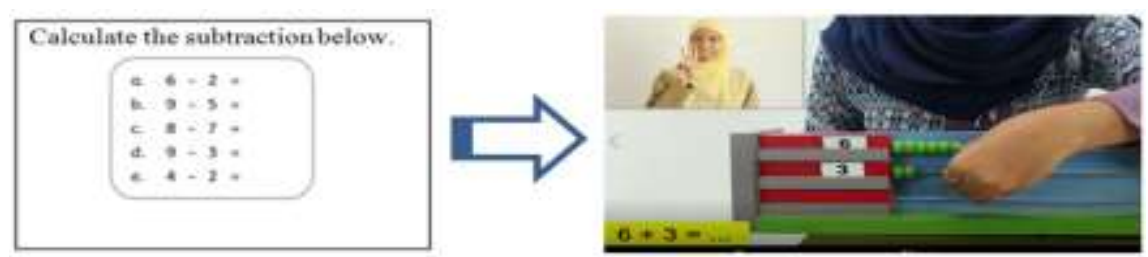

Figure 2

CwD can use Abacus Numbers to add/subtract two Integers

Results of Teaching Aids Implementation for CwD in ES through Joyful Learning

The effectiveness of the use of teaching aids for CwD needs to be implemented in ES. Benefits derived from the application of teaching aids in the ES including: (1) the initial benchmark of the student's imaginative growth in creating mathematical props; (2) knowledge whether or not there is an increase in the learning outcomes of the ES students after the introduction of students' learning of teaching aids; (3) the best vehicle to get a suitable and effective learning model in supporting the implementation of Joyful Learning.

Implementation of teaching aids in ES done by ES teachers observed by researcher and students of the research team. Before going to ES, the researcher has equipped students with the following knowledge. (1) Students are introduced with insights related to learning in ES and their language. (2) Students are introduced to the knowledge of Braille lettering or sign language for children with hearing impairment. (3) Students are introduced through a simulation of teaching techniques for $\mathrm{CwD}$ students in ES.

Table 2 below shows the results of mathematical tests before and after the implementation of mathematical teaching aids of students' work. The test is done twice with equivalent different questions. The first test is done before the implementation of teaching aids and the second test is done after the application of teaching aids.

Table 2

Results of Students Mathematics Test (Numerical Ability) of ESN Salatiga

\begin{tabular}{lllll}
\hline No & $\begin{array}{l}\text { Name of Student } \\
\text { (Code) }\end{array}$ & Disabilities Type & Score before AP usage & Scores after AP usage \\
\hline 1 & A1 & A/Blind & 80 & 86 \\
2 & B1 & B/Deaf & 50 & 74 \\
3 & B2 & B/ Deaf & 45 & 69 \\
4 & B3 & B/ Deaf & 22.5 & 56 \\
5 & B4 & B/ Deaf & 50 & 71 \\
6 & B5 & B/ Deaf & 35 & 60 \\
7 & B6 & B/ Deaf & 15 & 55 \\
8 & B7 & B/ Deaf & 72 \\
9 & C1 & C/Mentally disabled & 37.5 & 61 \\
10 & C2 & C/Mentally disabled & 12.5 & 12,5 \\
11 & C3 & C/Mentally disabled & 0 & 8 \\
12 & C4 & C/Mentally disabled & 75 & 80 \\
13 & C5 & C/Mentally disabled & 25 & 50 \\
14 & C6 & C/Mentally disabled & 50 & 64 \\
15 & C7 & C/Mentally disabled & 37.5 & 55 \\
16 & C8 & C/Mentally disabled & 62.5 & 76 \\
17 & C9 & C/Mentally disabled & 50 & 54 \\
\hline
\end{tabular}

International Journal of Instruction, July $2020 \bullet$ Vol.13, No.3 
Based on Table 2 above, it turns out that after the application of the use of teaching aids made by students conducted by ES teachers through Joyful Learning; it tends to increase the score on the second test results.

\section{Utilization of suitable teaching aids for CwD to Joyful Learning}

Based on the results of the second FGD that was attended by the research team, the ES teachers, lecturers of Mathematics Education who were interested, and the students who participated in teaching activities in ES, they have found and agreed on the use of Mathematical Model suitable for CwD in ES, (1) Teachers still have to master the teaching contents to ES students. (2) Teachers still need to optimize the use of teaching tools such as rulers, whiteboard, chalk or markers, LCD, or computer/internet utilization, including student and teacher books. (3) Teachers optimize the use and use of mathematical teaching aids appropriately. Audio-visual teaching aids are also possible to use. (4) Teachers need and strongly encouraged to involve ES students in teaching-assisted teaching aids. Teachers are not encouraged to dominate classroom conversations (need to be student oriented). (5) The skills of ES students also need to be improved so that students can use teaching aids to perform the tasks. Gradually, ES students have to grow their imagination, so they can do math problems without teaching aid. (6) Teacher's voice needs to be loud enough (except for deaf students), not in haste in explaining teaching contents, not angry/emotionally, and not hesitantly repeating if any ES students are unclear. (7) For joyful learning in ES then: (a) teachers need to be friendly to the students, courteous, patient, and always willing to help the ES students without any complaints from the teacher; (b) the teacher is willing to serve students who need to be assisted for the personal needs of students, such as helping to eat, washing hands, going the bathroom, or other similar; (c) teachers can bring ES students to study in an atmosphere of joy, harmony, and togetherness.

\section{DISCUSSION}

This research focused on preliminary observation of the initial growth of Imaginative Thinking Mathematically in some Mathematics Education students in designing and making teaching aids for $\mathrm{CwD}$ to the fun learning or Joyful Learning. Imaginative Mathematical Thinking that began to grow in some students of Mathematics Education in designing and making teaching aids for $\mathrm{CwD}$ to fun learning or Joyful Learning needs to be grown on many students as possible through planned, measurable, and sustainable activities.

As described in the literature review, the emergence of imagination requires creativity. Imagination and creativity are strongly needed in the future, including labor demand for example as a teacher at ES, as wrote by (Cunningham, 2015). To bring this imaginative into mathematical thinking programmed, measurable, and sustainable, there are some expert opinions on it like (Suyitno, 2017), and (Zhu, et al, 2018).

To generate imaginative in mathematical thinking to create teaching aids for $\mathrm{CwD}$ toward Joyful Learning, the indicator is chosen that fulfills one of the following: (1) the student is able to bring up the imagination or idea which is characterized by the production of different teaching aids (2) fluency, which is students have the ability to produce a teaching aids that can be utilized to explain some different teaching contents, 
(3) flexibility, which is the ability of students to produce some teaching aids that can be utilized for explaining a teaching content, or (4) originality, which is the ability of student capable of making a teaching aids as self-product without the help of other students.

From the implementation of this research, it can produce one or two products of manipulative teaching aids for $\mathrm{CwD}$ which is expected to be the model for next students teaching aids. It is hoped that the model of teaching aids as a result of this research can be trained face-to-face through Extra-Curriculum Training (ECT) activities. With this research, activity of ECT gives the result of the design and the results of the implementation of Teaching Aids for CwD toward Joyful Learning as the initial growth form of imaginative in students mathematical thinking, which is suitable with the needs of children who $\mathrm{CwD}$ and this teaching aids friendly to the environment.

\section{CONCLUSION}

From the results above and description on the discussion, then can be concluded as follows. (1) Initial grow of imaginative in mathematical thinking of Mathematics Education students need to be developed through the activity in the form of ExtraCurriculum Training (ECT) in the future. (2) Had been gotten the new ways how to grow the imaginative in mathematical thinking of students of Mathematics Education, namely through of Extra-Curriculum Training ECT). (3) Had been found some mathematical teaching aids that suitable for CwD who is studying in ES as an indicator of the growth of initial imaginative in the mathematical thinking of Mathematics Education students. (4) Student learning outcomes obtained by ES based on the application of mathematical teaching aids that suitable for $\mathrm{CwD}$ learning in ES toward Joyful Learning. There was a tendency can increase the quality of mathematics learning, because it could improve the score of the results of tests that had been carried out.

\section{SUGGESTIONS}

From the results of research and description on the discussion, it can be recommended suggestions as follows. (1) Activity-based on training in Mathematics Education Study Program of UNNES need to be held to grow the imaginatively in mathematical thinking for students. (2) Mathematical teaching aids that suitable for $\mathrm{CwD}$ who are studying at ES need to be thought up, designed, and made by students of Mathematics Education Study Program of UNNES. (3) Lecturers and students need to work synergy to develop the teaching aids for $\mathrm{CwD}$ through various activities.

\section{REFERENCES}

Afiff, F. (2013). Berpikir Imajinatif. Bandung: Fakultas Ekonomi. Universitas Padjadjaran.

Burns, M. (2011). Distance education for teacher training: Modes, models, and methods. Washington, DC: Education Development Center, Inc.

Conklin, H. (2014). Toward more joyful learning: integrating play into frameworks of middle grades teaching. American Educational Research Journal, 51(6), 1227-1255. 
Cunningham, C. (2015). Imagination: Active in teaching and learning (Unpublished master thesis). University of Nebraska.

Doyran, F. (Ed.). (2012). Research on teacher education and training: An introduction. Athens Institute for Education and Research.

Harwell, S. (2003). Teacher professional development: It's not an event, it's a process. Texas: CORD - P.O.

Kramarz, F., Bressoux, P., \& Prost, C. (2008). Teachers' training, class size and students' outcomes: Learning from administrative forecasting mistakes. IZA Discussion Paper No. 3871, 1-46.

Law of the Republic of Indonesia Number 20 of (2003). concerning the National Education System. Chapter IV Article 5 Paragraph (1).

Liang, C., Chang, C., Chang, Y., \& Lin, L. (2012). The exploration of indicators of imagination. TOJET, 11(3), 366-374.

Mayring, P. (2014). Qualitative content analysis: Theoretical foundation, basic procedures and software solution. Klagenfurt: SSOAR.

Miles, M., \& Huberman, A. (2014). Qualitative data analysis-A methods sourcebook. London: SAGE.

Salmi, H., Vainikainen, M., \& Thuneberg, H. (2015). Mathematical thinking skills, selfconcept and learning outcomes of 12-year-olds visiting a mathematics science centre exhibition in Latvia and Sweden. JCOM, 14(4), A03.

Onal, H., Inan, M., \& Bozkurt, S. (2017). A research on mathematical thinking skills: Mathematical thinking skills of athletes in individual and team sports. Journal of Education and Training Studies, 5(9), 133-139.

Sriraman, B. (2017). Dimensions of mathematical thinking and learning in ACCEL. Roeper Review, 39(3), 206-209.

Suyitno, A. (2017). Penelusuran Letak dan Penyebab Kesalahan dalam Mengerjakan Soal sebagai Basis untuk Pengungkapan Pertumbuhan Kreativitas Matematis Mahasiswa. A Dissertation that presented at the Mathematics Education of Postgraduate Program at Universitas Negeri Semarang. Universitas Negeri Semarang.

Tracy, J. (2013). Qualitative research methods. West Sussex: Wiley-Blackwell.

Wei, C., Hung, I., Lee, L., \& Chen, N. (2011). A joyful classroom learning system with robot learning companion for children to learn mathematics multiplication. TOJET: The Turkish Online Journal of Educational Technology, 10(2), 11-23.

Zhu, Y., Yu, W., \& Cai, J. (2018). Understanding students' mathematical thinking for effective teaching: A comparison between expert and nonexpert chinese elementary mathematics teachers. EURASIA J of Math, Sci and Tech Edu, 14(1), 213-224. 